ORIGINALN I ČLANAK

\title{
Exploring the profiles and motives of recreational divers. Case study from Greece
}

\author{
Istraživanje profila i motiva rekreativnih \\ ronilaca - studija slučaja iz Grčke
}

\author{
Dimitrios Mylonopoulos, University of West Attica, Athens, Greece \\ Polyxeni Moira, University of West Attica, Athens, Greece
}

ABSTRACT

Leisure diving with self-contained breathing apparatus is one of the fastest growing recreational activities in the world. According to the available data, more than 900,000

Keywords:

Recreational diving, Diving tourism,

Greece people every year are certified by the largest relevant certification body. Nowadays, more than 25 million certified divers are recorded worldwide. In parallel, the number of tourists engaged in diving for recreation in coastal resorts, the so-called "resort divers", is also increasing. The growing interest in diving as a maritime tourism activity is supported by the publication of special magazines and videos about the underwater world, the establishment of diving clubs, the operation of special diving boats and the creation of diving resorts. Said interest in the underwater world has resulted in the development of a special form of tourism, namely underwater or diving tourism. This study explores motivations for diving in Greece and has the objectives to understand the Greek divers' profiles, motivations to participate in diving activities and attitudes, as well as reasons for choosing a diving place. Another goal is to investigate whether the new institutional framework in Greece facilitates recreational diving or creates obstacles to divers. The results of the survey demonstrate that recreational diving is a new and dynamic field of alternative leisure activities with a great potential for further development and significant economic benefits for tourism destinations and Greece, in general. Its audience travels inside and outside Greece in order to enjoy the marine environment, but also to escape from everyday life, has a high-income profile and devotes several days to the destination. However, the current institutional framework in Greece, with big delays and considerable limitations for the demarcation of the areas open to scuba diving, seems to be an impediment for the development of this form of special interest tourism. 


\begin{abstract}
Ključne reči:
Rekreativno

ronjenje,

ronilački turizam,

Grčka

ronilačke sertifikate od najvećeg nadležnog tela. Trenutno u svetu postoji više od 25 miliona registrovanih ronilaca. Uporedo sa tim raste i broj turista (takozvanih "resort divers") koji se bave rekreativnim ronjenjem u priobalnim odmaralištima. Porast interesovanja za ronjenje kao aktivnost maritimnog turizma prate i specijalna izdanja časopisa i filmova o podvodnom svetu, osnivanje ronilačkih klubova, postojanje i rad posebnih čamaca za ronjenje i otvaranje odmarališta namenjenih roniocima. Ishod pomenutog interesovanja za podvodni svet je i razvoj posebnih oblika turizma - takozvanog podvodnog ili ronilačkog turizma. Ova studija istražuje motive za ronjenje u Grčkoj i ima za cilj da razume profile ronilaca u Grčkoj, motive za učešće u ronilačkim aktivnostima, kao i razloge, odnosno stavove vezane za izbor mesta za ronjenje. Jedan od ciljeva je i uvrđivanje toga da li novi institucionalni okvir u Grčkoj olakšava rekreativno ronjenje ili stvara prepreke roniocima. Rezultati istraživanja pokazuju da je rekreativno ronjenje novo i dinamično polje alternativnih aktivnosti slobodnog vremena sa velikim potencijalom za razvoj i značajnim ekonomskim profitom, kako za turističke destinacije, tako i za celu Grčku. Ronioci putuju u Grčku i u inostranstvo kako bi uživali u pomorskim aktivnostima, ali i kako bi pobegli od svakodnevice, imaju visoke prihode i posvećuju nekoliko dana svakoj destinaciji. Međutim, čini se da trenutni institucionalni okvir u Grčkoj, sa velikim kašnjenjima i znatnim ograničenjima za demarkaciju oblasti dostupnim roniocima sa bocom, predstavlja prepreku ovom obliku turizma posebnih interesovanja.
\end{abstract}

TIMS Acta (2019) 13, 5-14

\section{Introduction}

The underwater world is a mysterious and unexplored world for man. According to loannidou (2014, p.11), the verb "dive", from which the words diving and diver come from, is found in the Homeric epics (in the middle of the 8th century). Searching for food, observing the marine world, and inspecting for reefs dangerous for ships were some of the main reasons that prompted people to dive. A large percentage of divers were fishermen of shellfish, sponges, corals, etc. Since the antiquity, Greek sponges' fishermen have been widely known for diving in the deep ocean depths.

Apart from sponges' divers, there were also sailors, people who explored the conditions of the bottom of the sea, the hull of the boat, mooring, etc. The role of the divers, who, by taking part in naval operations, were acting to sabotage enemy ships, was also very important. In Herodotus (Hро́ботоৎ, Іоторіal, 8.6.18.16.3), reference is made to the Greek Scyllis (500 BC) from Skionis, who was the first diver of his time. Scyllis was captured by the Persian King Xerxes I and held in his camp in Afetes. But when he learned that Xerxes would invade Greece, he burst and dug into the sea. Using a hollow reed that allowed him to breathe under the water could pass unnoticed. The Persians failed to identify him and believed he was drowned. Scyllis emerged from the water at night, passed through the Persian fleet and cut off the ropes that fastened the Persian ships. Then, he swam nine miles and found the Greek fleet at Cape Artemisio.

Finally, as there were several shipwrecks in the Mediterranean Sea, due to the large volume of trade, divers were often recruited to retrieve goods that had been immersed with the ships. Due to the danger of the divers' profession, the first laws regulating the remuneration of those taking part in the wreckage of shipwrecks, such as the "Rhodian Maritime Law / Lex Rhodia", were stipulated (Mylonopoulos, 2011, p. 24).

In broad terms, insecurity and the inability to access the underwater environment resulted in human reluctance to engage in activities that brought him into contact with the seabed. Due to the developments in the field of technology coupled with the influence of television, photography and books, the general public has come into contact with the marine environment and the organisms living in it. In particular, the famous documentaries of the French explorer Jacques-Yves Cousteau' has increased man's knowledge of the underwater world and sparked a desire to get to know it. As a result, increased interest in diving was promoted and, more generally, the desire to explore and enjoy the underwater marine environment. Soon a new diving form was created, aimed at the general public, the so-called "recreational diving".

Today, scuba diving can be divided into four categories, namely diving of scientific interest, diving related to martial activities, professional scuba diving and recreational diving. 


\section{Diving activity}

In the effort to get to know the underwater world, and because of the rapid evolution of technology, man increasingly improves diving methods and tools. While recreational diving was initially considered being a hard adventure activity, thanks to the technology that turned it more affordable and thus accessible to the general public, it developed into a soft adventure activity. Free diving, snorkeling, scuba diving and surface supplied diving are nowadays developed as recreational diving activities. In particular, the form of diving known as SCUBA (SelfContained Underwater Breathing Apparatus) significantly increased the number of people involved in diving and gave impetus to the development of a new form of tourism, the so-called "underwater" or "diving tourism" (Mylonopoulos \& Moira, 2005, p. 67).

Many scholars (Dignam, 1990; Tabata, 1990 as cited in Orams, 1999) argue that diving with a breathing machine is among the fastest growing leisure activities in the world and is an expanding component of the tourism industry (Tabata, 1992; Wilks \& Davis, 2000; Edney, 2006; Thapa, Graefe, \& Meyer, 2006). According to the figures, more than 900.000 people are certified each year by the largest divers' certification organization, with more than 25 million divers being certified in total worldwide (PADI, 2017). In the United States, the estimated number for scuba divers amount to 2.7-3.5 million at a total of 6 million worldwide and about 11 million snorkelers versus 20 million around the world. These activities contribute US 11 billion dollars to the US GDP (DEMA, 2017).

Although diving with a self-contained underwater breathing apparatus is considered as an adventure activity, similar to climbing, rafting, mountain biking, skiing and skydiving (Travel Industry Association of America, 1998), there is a recorded increase of the interest of people for diving as a maritime tourism activity. This increase is enhanced by the publication of magazines of special interest and videos concerning the underwater world, the establishment of diving clubs, the operation of special diving boats and the creation of diving resorts. At the same time, the number of tourists engaged in diving for recreation in coastal resorts, the so-called "resort divers", is increasing.

Today, diving creates an important area of economic activity, which could be described as a "diving tourism industry". Said tourism economic activity includes businesses selling diving equipment, diving schools, transport services with specialized ships in diving sites, promotion and advertising companies for diving sites, diving tourism resorts, companies of special interest printed and electronic press, travel agencies dealing exclusively with diving, etc.

Many of the major diving destinations are outside the European territory (e.g. Maldives, Indonesia, Micronesia, the Red Sea, Mexico, Australia and Hawaii), which results in a significant leak in currency. According to the existing data, there are more than 25 million certified divers worldwide, including 4 million Europeans, spending more than 2 billion euros a year (Yassirani, 2017).

The national income of many countries is heavily dependent on diving tourism (e.g. Indonesia, Malaysia), while for other countries it is a major source of foreign exchange (e.g. Maldives, Malta, Egypt, etc.).

Greece has 9,835 islands, with a total coastline of 15,021 $\mathrm{km}$ (data from Hellenic Navy Hydrographic Service, Map 1), exceptional climate conditions, rich history and cultural heritage, as well as marine flora and fauna. The valorisation of these features constitutes a solid basis for the development of diving tourism and the establishment of Greece as a top diving destination throughout the year.

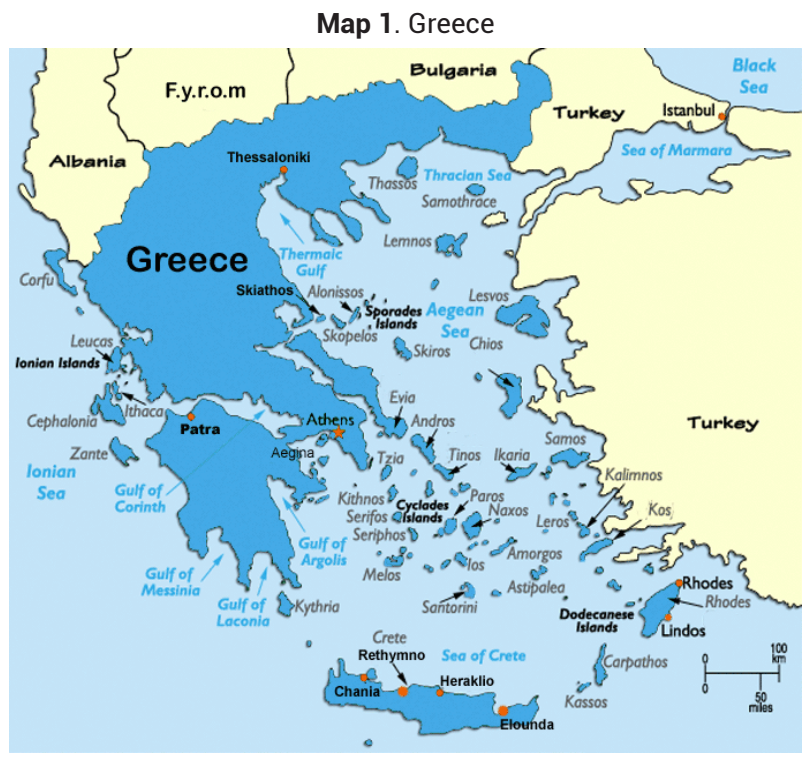

Source: Map of Greece (2019).

(Available at http://www.greek-islands.us/map-greece/)

\section{The institutional framework of diving tourism in Greece}

In general, underwater activities, with a breathing apparatus or other underwater means for recreational purposes, are permitted throughout the country. 
However, there are various restrictions on diving activity in underwater archaeological sites and ecologically sensitive marine ecosystems and protected areas. The definition of these areas is made by a joint decision of the competent ministers, namely the Ministers of Culture and Shipping in the first case, and the Ministers of Environment and Shipping in the second case. The joint competency of several Ministries in a wide range of issues related to underwater activities, namely the Ministries of Shipping, Culture, Environment and Tourism, as well as the contradictory provisions governing them, have often created significant impediments to the development of diving tourism.

The Greek state, recognizing the importance of diving tourism as a form of special interest tourism, acted to establish a specific legal framework for recreational diving by Law 3409/2005 (Government Gazette A'273). According to this law, the practice of underwater activity with a breathing apparatus or other underwater means for recreational or sport purposes and the training of divers and diving instructors are subject to the supervision and control of the Ministry of Shipping and Island Policy. The latter also maintains a registry of licenses for the enterprises offering services of recreational diving.

Moreover, this Law stipulates, for the first time, Areas for the Organized Development of Diving Parks. The decision for the designation and delimitation of marine spaces as Areas for the Organized Development of Diving Parks is taken by the Ministry of Environment and Energy. The purpose of the provision is to regulate the activities within the diving parks, open to the public for recreational diving, diving training and scientific research. Within this framework, inter alia, diving parks can be a pole of attraction for recreational divers. The Law also provides for the punishment of the offenders and threatens with imprisonment for a minimum of three months the person carrying out the activity of a provider of leisure diving services without the intended license. Additionally, an administrative penalty, taking the form of a fine, is provided.

Furthermore, the said Law provides for the possibility of defining marine archaeological sites as "underwater museums", where guided diving is allowed by divers who are guardians of antiquities or archaeologists. A designation of this kind took place 10 years after the passing of the Law, with a Joint Ministerial Decision [\$53/12387/6960/772/240/21-1-2015 (Government Gazette B'119)], referred to the islands of Sporades and West Pagasitikos, Magnesia, Thessaly Region. These sites have been designated as open-to-the-visitors archaeological sites and can also function as underwater museums.

Today, 3 years later, the relevant programme conventions have not yet been signed and the sites are not open to the public. Also, there are no statistics available on the number of operative diving centres in Greece, the number of certified recreational divers and general data on the demand for this special form of tourism.

\section{Aim of the study/Methodology}

Several studies have been carried out on diver motivations, preferences, satisfaction, behaviour and attitudes. These studies refer to divers in Australia (Davis, 1997; Jewell, 2004; Stolk, Markwell, \& Jenkins, 2005), in the Carribean and Fiji islands (Uyarra, Watkinson, \& Côté, 2009), in Florida Keys and Northern Florida (Meyer, Thapa, \& Pennington-Gray's, 2003; Meisel \& Cottrell, 2004) and recently in Azores (Bentz, Lopes, Calado, \& Dearden, 2016). There are no similar studies about diving motivations in Greece, except few articles about the legal status of marine protected areas in Greece (Mylonopoulos, Moira, \& Parthenis, 2011; Gerovassileiou, Koutsoubas, Sini, \& Paikou, 2009).

This study explores motivations for diving in Greece and has the objectives: to understand the Greek divers' profile, motivations to participate in diving activities and attitudes, as well as the reasons for choosing a diving place. Another goal is to investigate whether the new institutional framework in Greece facilitates recreational diving or creates obstacles to divers.

In order to examine the profile and motives of Greek recreational dives, a primary survey was carried out by distributing a structured questionnaire. The questionnaire was created by the authors and was distributed to members of legally operating diving clubs in Greece, via email. The distribution was made by a certified diver and diving club member. The questionnaire was sent to other members of the same or other diving clubs and to other independent divers. The survey was conducted from $01 / 10 / 2017$ to $31 / 12 / 2017$. A total of 105 structured questionnaire were distributed and 98 (93.3\%) of them were returned and completed.

The questions were divided into two categories: the first concerned independent variables that mainly looked at personal data of respondents, such as gender, age, 
nationality, occupation, education, income level, and the second concerned elements identifying their profile as recreational divers (certification as divers, years of diving, time for diving, preferred travelling period, reasons for diving, etc.).

There were two inherent limitations in the sampling approach. First, the fact that the questionnaire was electronically distributed, involve a bias against those potential respondents who don't have access to a computer, particularly those without an internet connection or connection with social media. Secondly, the sample, due to the lack of data on the number of operative diving centres in Greece, and the number of certified recreational divers, is not representative but a sample of convenience.

\section{Findings/Discussion}

A total of 80 men (81.6\%) and 18 women (18.4\%) responded to the questionnaire, confirming the view that men are mainly engaged in this activity (Tabata, 1992; Ditton \& Baker, 1999; Mundet \& Ribera, 2001). 40\% (39 persons) were $31-40$ years old, $28.3 \%$ (28 persons) were 41-50 years old and $15 \%$ (15 persons) were $20-30$ years old (Table 1). As it is demonstrated by other studies, the dominant (68.3\%) age group is between $31-50$ years (Mundet \& Ribera, 2001, p. 505). Younger people, i.e. up to 30 years old, account for only $16.7 \%$. This is probably related to the fact that recreational diving has a relatively high cost, difficult to be covered by young people.

Table 1. Age of recreational divers

\begin{tabular}{ccc}
\hline Age & Frequency & $\%$ \\
\hline$<19$ years old & 2 & 1.7 \\
$20-30$ years old & 15 & 15.0 \\
$31-40$ years old & 39 & 40.0 \\
$41-50$ years old & 28 & 28.3 \\
$51-60$ years old & 11 & 11.7 \\
$>61$ & 3 & 3.3 \\
\hline TOTAL & 98 & 100 \\
\hline
\end{tabular}

(Source: Authors)

In terms of nationality, 90 (91.6\%) of the 98 respondents were Greeks, while 6 Cypriots and two Germans (permanent residents in Greece) have also responded. $38 \%$ (37 people) were graduates of tertiary education, $25 \%$ (24 persons) were holders of a postgraduate degree, $22 \%$ (22 persons) were secondary school graduates and $15 \%$ (15 persons) were graduates of a higher school.

As far as the marital status is concerned, $51 \%$ declared that they were married and $49 \%$ were single. $38.8 \%$ of the respondents (38 persons) were employees in the private sector, $26.6 \%$ (26 persons) were businessmen and $16.4 \%$ (16) were civil servants. Lower rates were recorded for pensioners and contract staff members (from 5 people), diving instructors (3), military officers (3) and students (2) (Table 2).

Table 2. Profession of recreational divers

\begin{tabular}{lcc}
\hline \multicolumn{1}{c}{ Profession } & Frequency & Percentage \% \\
\hline Civil servant & 16 & 16.4 \\
Employees of the private sector & 38 & $\mathbf{3 8 . 8}$ \\
Businessmen & 26 & $\mathbf{2 6 . 6}$ \\
Housewife & - & - \\
Pensioners & 5 & 5.1 \\
Military officers & 3 & 3.0 \\
Students & 2 & 2.0 \\
Contract staff members & 5 & 5.1 \\
Diving instructor & 3 & 3.0 \\
\hline \multicolumn{1}{c}{ TOTAL } & $\mathbf{9 8}$ & $\mathbf{1 0 0}$ \\
\hline
\end{tabular}

(Source: Authors) 
$63.3 \%$ of the respondents (62 persons) reported that they have been active in the area for about 4 to 10 years, $30.6 \%$ (30 persons) stated that they have been active for more than 10 years and $6.1 \%$ (6 persons) less than 3 years. What turns out is that this activity is not an ephemeral experience but continues to keep the interest of the practitioners for a long time.
The personal monthly income of the respondents is for $32.7 \%$ (32 persons) between 1,201-1,500 euros, for $24.5 \%$ (24 persons) between 901-1,200 euros, for 14.3\% (14 persons) above 1500 euros and between 601-900 euros. Also, $11.2 \%$ stated that their income is between $301-600$ euros and $3 \%$ said their income is below 300 euros per month (Table 3).

Table 3. Personal monthly income of recreational divers

\begin{tabular}{ccc}
\hline Personal income in euros & Frequency & Percentage \% \\
\hline$<300$ & 3 & 3.0 \\
$301-600$ & 11 & 11.2 \\
$601-900$ & 14 & 14.3 \\
$901-1200$ & 24 & 24.5 \\
$1.201-1.500$ & 32 & 32.7 \\
$>1.500$ & 14 & 14.3 \\
\hline TOTAL & 98 & 100 \\
\hline
\end{tabular}

(Source: Authors)

Respondents were then asked to determine the amount they have spent on average for their equipment (mask, wetsuit/dry suit, fins, flashlight, safety equipment, etc). The highest figure was more than EUR 1,500 (54.2\%), which is normal, since good quality equipment is essential for safe diving (Table 4).

Asked how they were informed and how they started diving, a high percentage of respondents $-40.9 \%$ (40 people) said they learned about diving from friends, were not trained and certified.
$25.6 \%$ (25) from their family and $13.3 \%$ (13 people) from the internet. A very low percentage stated they learned about diving from school (5.1\%, 4 people), television (6.1\%, 6 people), during their military service, from a diving club, workplace, etc. $45.9 \%$ said they were a member of a diving club while $54.1 \%$ said they were acting independently. 95\% (93 people) of respondents said they had a diving certificate i.e. they were certified by a competent body, while only $5 \%$ ( 5 people) said they

Table 4. Amount spent for basic equipment

\begin{tabular}{|c|c|c|}
\hline Average of spending in euros & Frequency & Percentage \% \\
\hline$<200$ & 5 & 5.1 \\
\hline $201-500$ & 6 & 6.1 \\
\hline $501-800$ & 8 & 8.1 \\
\hline $801-1.100$ & 11 & 11.2 \\
\hline $1.101-1.500$ & 15 & 15.3 \\
\hline$>1.500$ & 53 & $\mathbf{5 4 . 2}$ \\
\hline TOTAL & $\mathbf{9 8}$ & $\mathbf{1 0 0}$ \\
\hline
\end{tabular}

(Source: Authors)

The overwhelming majority, namely $81.7 \%$ ( 80 people) said that they are practicing recreational diving all year round, $15.7 \%$ (16 people) only in the summer and $2 \%$ (2 people) only in the winter. It turns out that diving is an activity that is practiced all year long, so it could, if properly promoted, significantly prolong the tourist season of the country.

$53.1 \%$ of the respondents (52 people) said they are diving in Greece, in various destinations and mainly in islands, such as Kos, Kalymnos, Rethymnon, Lefkada, Kythnos, Milos, etc. $44.9 \%$ (44 people) said they are diving abroad, with Cyprus and the Red Sea being the dominant destinations. Only two people said they are doing diving both in Greece and abroad.

A high percentage of $73.1 \%$ (38 people) of scuba divers in Greece said they are staying at the destination from 4-6 days, while $15.3 \%$ said they are staying from 7 to 10 days. Similarly, those who prefer diving at destinations 
abroad stated, to a percentage of $41 \%$ (18 persons), that they stayed for $7-10$ days, $31.8 \%$ (14 persons) from 4 to 6 days and $22.7 \%$ (10 persons) that they are staying for up to 3 days.

The majority $(62.2 \%$, i.e. 61 people) said that they are diving with a group of $1-3$ persons, $26.5 \%$ (26 persons) with a group of $4-6$ and $8.2 \%$ (8 persons) with a group of more than 6 people. Only $3.1 \%$ said they were diving without companionship.

The next question was about the reasons for diving. The majority of respondents (86.7\%) stated the enjoyment of the marine environment and of the seabed. The answers that followed were "escape" from everyday life (79.6\%) and recreation (71.4\%). 49\% said they desire a closer contact with nature and $51 \%$ that they like the exploration. A percentage of $35.7 \%$ said they are attracted by the risk and challenges this activity entails. Another percentage (35.7\%) said they were attracted by the challenges of the destination, the degree of risk, etc. Finally, $13.3 \%$ stated they are doing scuba diving because they have underwater photography as a hobby, while 8 people mentioned other reasons, with 4 of them reporting business reasons (Table 5).

Table 5. Reasons for diving

\begin{tabular}{llcc}
\hline \multicolumn{1}{c}{ Reasons for diving } & Frequency & Percentage \% \\
\hline 1. & Recreation & 70 & 71.4 \\
2. & "Escape" from everyday life & 78 & $\mathbf{7 9 . 6}$ \\
3. & Enjoyment of the marine environment & 85 & $\mathbf{8 6 . 7}$ \\
4. & Training & 30 & 30.6 \\
5. & Exploration & 50 & 51.0 \\
6. & Contact with nature & 48 & 49.0 \\
7. & Challenges / risk & 35 & 35.7 \\
8. & Underwater photography & 13 & 13.3 \\
9. & Other & 8 & 8.2 \\
\hline
\end{tabular}

(Source: Authors)

Furthermore, in the question about the reasons for selecting a destination for recreational diving, the highest percentage responded "the rich underwater environment" and "the existence of underwater antiquities" (96.9\%), "the existence of wrecks" (94. 9\%), the clarity of sea water and good climate conditions to do scuba diving (86.7\%), infrastructure quality $(71.4 \%)$, etc. (Table 6). The ease of issuing permits (32.6\%), safety and security (25.5\%) and any additional offers of the destination (15.3\%) were reported as less relevant. Prices were reported as a quite important variant (43.9\%), which can be explained by the fact that diving requires a satisfactory level of income.

Table 6. Reasons for selecting a destination

\begin{tabular}{|c|c|c|c|}
\hline & Reasons for selecting a destination & Frequency & Percentage \% \\
\hline 1. & Safety and security & 25 & 25.5 \\
\hline 2. & Clarity of waters & 85 & 86.7 \\
\hline 3. & Additional offers & 15 & 15.3 \\
\hline 4. & Easy access & 78 & 79.6 \\
\hline 5. & Ease of issuing permits & 32 & 32.6 \\
\hline 6. & Good weather conditions & 85 & 86.7 \\
\hline 7. & Rich underwater environment & 95 & 96.9 \\
\hline 8. & Quality infrastructure & 70 & 71.4 \\
\hline 9. & Prices & 43 & 43.9 \\
\hline 10. & Existence of underwater antiquities & 95 & 96.9 \\
\hline 11. & Wrecks & 93 & 94.9 \\
\hline 12. & Other & 34 & 34.7 \\
\hline
\end{tabular}

(Source: Authors) 
To note that all replies exceeded $100 \%$ as respondents were free to choose more than one answer.

Finally, in the question of whether they know the legislation governing recreational diving in Greece, 92.8\% (91 persons) responded positively. From these, 12 consider that the current institutional framework is an impediment to the development of recreational diving due to bureaucracy for obtaining the license (33\%), the inspections carried out by the competent authorities (31\%), the high cost of issuing the license (15\%) and for other non-listed reasons.

\section{Conclusions}

Diving tourism is a tourism product developed and promoted worldwide as a special form of tourism. Trying to meet the contemporary expectations and requirements for the development of special interest tourism, the Greek state has established a specific legal framework for recreational diving.

Recreational divers in Greece are mostly men (81.6\%), well-educated (63\%), 31-50 years old (68.3\%) with a personal monthly income between 1,201-1,500 euros (32.7\%). The findings coincide with relevant studies showing that divers are predominantly male and welleducated, (Davis, 1997; Ditton, Osburn, Baker, \& Thailing, 2002; Musa, 2002, p. 200; Musa, Seng, Thirumoorthi, \& Abessi, 2010, p. 7) with income higher than average (Davis, 1997; Stolk, Markwell, \& Jenkins, 2007, p.228). The findings coincide also with relevant studies about the divers' age (Stolk et al, 2005:161; Stolk, et al., 2007, p. 228; Musa et al., 2010, p. 7; Uyarra et al., 2009, p. 16).

Enjoyment of the marine environment and experiencing marine life has been declared to be one of the most important motivations for scuba diving, along with exploration, relaxation (escape from everyday life), adventure and excitement/challenges-risk (Davis, 1997; Ditton et al., 2002; Meisel \& Cottrell, 2004; Stolk, et al., 2005).

The largest percentage has spent more than 1,500 euros (54.2 percent) on equipment, since good quality equipment is essential for safe diving. A big majority of $40.9 \%$ said they were initiated in diving by friends and $45.9 \%$ are members of a diving club. 95\% of them have a diving certificate and $81.7 \%$ are doing diving throughout the year. $53.1 \%$ are diving in Greece, in various destinations, especially in the Greek islands, while $44.9 \%$ are diving in destinations abroad, with Cyprus and the Red Sea being the dominant destinations. Scuba diving in Greece, for $73.1 \%$, lasts from 4-6 days, while abroad scuba divers stay from 4-6 days (41\%). The big majority (62.2\%) prefers diving within a group of 1-3 people in order to enjoy the marine environment and the seabed (86.7\%), as well as "escape" from everyday life $(79.6 \%)$ and for recreational reasons $(71.4 \%)$. The reasons for selecting an area for recreational diving are the "rich underwater environment" and the "existence of underwater antiquities" (96.9\%), the "existence of wrecks" (94.9\%), the clarity of sea water and good weather conditions (86.7\%), the infrastructure quality $(71.4 \%)$, etc. Finally, $92.8 \%$ are aware of the current legal framework in Greece for recreational diving but 33\% consider that this is a deterrent to its development.

In conclusion, recreational diving seems to be a dynamic field of special interest tourism with strong potential for further development. Since recreational divers are willing to travel to enjoy the marine environment, they are classified as high-end tourists in terms of disposable income and they stay several days at the destination.

However, the current institutional framework in Greece, with big delays and considerable limitations for the demarcation of the areas open to scuba diving, seems to be an impediment for the development of this form of tourism.

\section{REMARKS}

1 Jacques-Yves Cousteau was a French Navy officer, explorer and researcher, who studied the sea and all forms of marine life. He was born in France in 1910 and died in 1997 in Paris, leaving behind a rich research work. With the famous documentaries of The Silent World, The Golden Fish and World Without Sun, he won three Oscars as well as other awards, such as the Golden Phoenix at the Cannes Film Festival in 1956. With his work, he brought the general audience closer to the underwater biology. In addition, he has allowed people from all continents to experience life in the oceans and explore, through the television, the sources of the "Blue Continent". His name became synonymous to devotion, adventure, nature and exploration (Cousteau \& Dumas, 1953; Cousteau \& Dugan, 1963; Cousteau \& Dugan, 1965; Cousteau, 2018)

\section{IZJAVA}

Autori su svojim izjavama potvrdili nepostojanje bilo kakvog sukoba interesa. 


\section{REFERENCES}

Bentz, J., Lopes, F., Calado, H., \& Dearden, Ph. (2016). Understanding diver motivation and specialization for improved scuba management. Tourism in Marine Environments, 12(1), 35-49.

Cousteau, J.Y. (2018). The Captain Cousteau. Retrieved from https:// www.cousteau.org/english/the-captain.php

Cousteau, J.Y., \& Dugan, J. (1963). The Living Sea. New York: Harper and Row.

Cousteau J.Y., \& Dugan, J. (1965). World Without Sun. New York: Harper and Row.

Cousteau J.Y., \& Dumas, F. (1953). The Silent World. New York: Ballantine Books.

Davis, D. (1997). The development and nature of recreational scuba diving in Australia: A study in economics, environmental management and tourism, Doctor of Philosophy, University of Queensland, St Lucia, Queensland.

DEMA (2017). Fast Facts: Recreational scuba diving and snorkelling. Retrieved from https://c.ymcdn.com/sites/www.dema.org/ resource/resmgr/imported/Diving\%20Fast\%20Facts-2013.pdf

Dignam, D. (1990, March, 1). Scuba diving among mainstream travellers. Tour and Travel News, 26, 44-45

Ditton, R.B., \& Baker, T.L. (1999). Demographics, attitudes, management preferences, and economic impacts of sport divers using artificial reefs in offshore Texas waters: Technical Report no. HD-99-01, https://repositories.tdl. org/tamug-ir/bitstream/handle/1969.3/26768/10275Demographics\%2C\%20Attitudes\%2C\%20Management\%20 Preferences\%2C\%20and\%20Economic\%20Impacts\%20of\%20 Spo. doi:10.1006/jmsc.2002.1188

Ditton, R.B., Osburn, H.R., Baker, T.L., \& Thailing, C.E. (2002) Demographics, attitudes, and reef management preferences of sport divers in offshore Texas waters. ICES- Journal of Marine Science, 59, S186-S191.

Edney, J. (2006). Impacts of recreational scuba diving on shipwrecks in Australia and the Pacific: A review. Micronesian Journal of the Humanities and Social Sciences, 5(1/2), 201-233.

Gerovassileiou, V., Koutsoubas, D., Sini, M., \& Paikou, K. (2009). Marine protected areas and diving tourism in the Greek Seas: Practices and perspectives. Tourismos: An International Multidisciplinary Journal of Tourism, 4(4), 181-197.

Ioannidou, C.E. (2014). Diving in Ancient Greece during the late archaic and classical period (6th-4th century BC). Archaeology and Science, Belgrade, 111-119; 10.

Jewell, B. (2004). The effectiveness on diver attitudes and awareness of underwater shipwreck values -SS Yongala, a case study. Bulletin of the Australasian Institute for Maritime Archaeology, 28, 43-62.

Joint Ministerial Decision $\$ 53 / 12387 / 6960 / 772 / 240 / 21-1-2015$

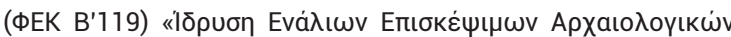

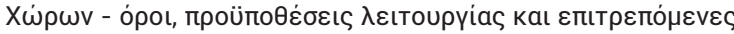

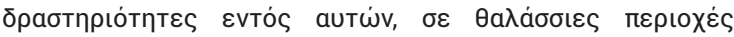

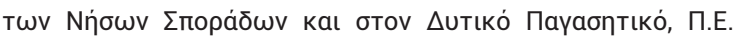

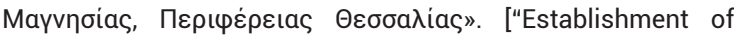
Underwater Archaeological Sites Open to Visitors- terms, conditions of operation and permitted activities within them, in the marine areas of Sporades Islands and West
Pagasitikos, Magnesia, Thessaly"] in Greek. Retrieved from http://www.et.gr/idocs-nph/search/pdfViewerForm. html?args=5C7QrtC22wE4q6ggiv8WTXdtvSoCIrL8NZ_IN6aNQ55MXD0LzQTLf7MGgc023N88knBzLCmTXKaO6fpVZ6LX 3UnKI3nP8NxdnJ5r9cmWyJWelDvWS_18kAEhATUkJb0x1LId Q163nV9K--td6Slua1wpdY4gS7NMwCz-2WFGfZSIDgxpQ3sc9ndaExS4-aK

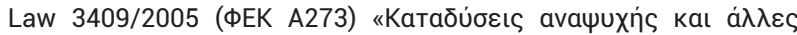

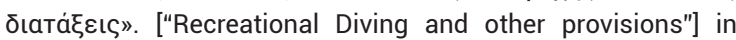
Greek. http://www.et.gr/idocs-nph/search/pdfViewerForm.

Meisel, C., \& Cottrell, S. (2004). Differences in motivations and expectations of divers in the Florida Keys. Paper presented at the Proceedings of the 2003 Northeastern Recreation Research Symposium, Bolton Landing, NY.

Meisel, C., \& Cottrell, S. (2004). Differences in motivations and expectations of divers in the Florida Keys. Paper presented at the Proceedings of the 2003 Northeastern Recreation Research Symposium, Bolton Landing, NY.

Meyer, L. A., Thapa, B., \& Pennington-Gray, L. (2003). An exploration of motivations among SCUBA divers in north central Florida. Paper presented at the Proceedings of the 2002 Northeastern Recreation Research Symposium, Bolton Landing, NY.

Mundet, L. \& Ribera L. (2001). Characteristics of divers at a Spanish resort. Tourism Management 22(5), 501-510.

Musa, G. (2002). Sipadan: A scuba-diving paradise: An analysis of tourism impact, diver satisfaction and tourism management. Tourism Geographies, 4(2), 195-209.

Musa, G., Seng, W. T., Thirumoorthi, T., \& Abessi, M. (2010). The influence of scuba divers' personality, experience, and demographic profile on their underwater behaviour. Tourism in Marine Environments, 7(1), 1-14.

Mylonopoulos, D. (2011). Maritime Law. Athens: Stamoulis. in Greek.

Mylonopoulos, D., Moira, P. \& Parthenis, Sp. (2011). The legislative framework of the management of the protected areas in Greece. The case of the National Marine Park of Zakynthos. In: Micallef, A. (ed), MCRR3-2010 Conference Proceedings, Journal of Coastal Research, Special Issue, No 61, (pp. 173-182). Grosseto. Tuscany, Italy.

Mylonopoulos, D., \& Moira, P. (2005). Marine Tourism. Athens: Interbooks. in Greek.

Orams, (1999). Marine Tourism.Development, Impacts and Management. London.

PADI. (2017). Worldwide Corporate Statistics 2017: Data for 2011 2016. https: //www. Padi. Com/sites/default/files/2/2017\%20 PADI\%20WW\%20Statistics.Pdf.

Stolk, P., Markwell, K. \& Jenkins, J.M. (2007). Artificial Reefs as Recreational Scuba Diving Resources: A Critical Review of Research. Journal of Sustainable Tourism, 15(4), 331-350.

Stolk, P., Markwell, K., \& Jenkins, J. (2005). Perceptions of artificial reefs as SCUBA diving resources: A study of Australian recreational SCUBA divers. Annals of Leisure Research, 8(2/3), $153-173$.

Tabata, R.S. (1992). Scuba diving holidays. In B. Weiler \& C.M. Hall (Eds.), Special Interest Tourism (pp. 171-184). London: Belhaven.

Thapa, B., Graefe, A. R., \& Meyer, L. A. (2006). Specialization and marine based environmental behaviours among SCUBA divers. Journal of Leisure Research, 38(4), 601-615. 
Travel Industry Association of America. (1998). The adventure travel report 1997. Washington, D.C.. doi:https://journals.sagepub. com/doi/10.1177/0047287598037001111

Uyarra, M.C., Watkinson, A.R., \& Côté, I.M. (2009). Managing dive tourism for the sustainable use of coral reefs: Validating diver perceptions of attractive site features. Environmental Management, 43, 1-16.

Wilks, J., \& Davis, R.J. (2000). Risk management for SCUBA diving operators on Australia's Great Barrier Reef. Tourism Management, 21, 591-599.

Yassirani, H. (2017). Diving into underwater tourism in Greece. European Commission. 04/10/2017, http://ec.europa. eu/regional_policy/en/newsroom/news/2017/10/10-042017-diving-into-underwater-tourism-in-greece. Retrieved from https://ec.europa.eu/regional_policy/en/newsroom/ news/2017/10/10-04-2017-diving-into-underwater-tourismin-greece

Нро́ботоৎ, бторіац. Pieces for the Greek Language. (8.6.1-8.16.3) [Herodotus, Histories], http://www.greek-language.gr/ digitalResources/ancient_greek/library/browse.html?text_ id=30\&page=196. Retrieved from http://www. greek-language. $\mathrm{gr} /$ digitalResources/ancient_greek/library/browse.html?text_ id $=30 \&$ page $=196$

Datum prijave: 02.12.2018.

Datum prihvatanja: 21.05.2019.

\section{Kontakt}

Dimitrios Mylonopoulos, University of West Attica, Department of Tourism Management, Greece

Agiou Spiridonos 28, Aegaleo, 12243

E-mail: dimilon@uniwa.gr

Polyxeni Moira, University of West Attica,

Department of Tourism Management, Greece

Agiou Spiridonos 28, Aegaleo, 12243

E-mail: polmoira@uniwa.gr 